\title{
APPROACHES TO RANKING CAUSES OF MANAGEMENT CRISES IN AN INDUSTRIAL AND COMMERCIAL ASSOCIATION
}

\begin{abstract}
The paper presents the improved method for ranking causes of management crises in industrial and commercial associations (ICA) in the changing environment, the peculiarity of which is designing management procedures focused on groups of similar causes of problem situations. Visualization of a set of causes leading to emergence of problem situations allows making more thorough decisions concerning the impact to be made on a particular object of ICA to ensure its economic security.
\end{abstract}

Key words: economic security, rehabilitation, ranking causes, situational approach, managerial situation, industrial and commercial associations.

Statement of the problem. Changes in the global and national economic environment require changes in paradigms and concepts of managing rehabilitation of ICAs in an attempt to make them adequate, using special methods, appropriate methods of calculation etc. and providing efficient planning, organizing, motivating, controlling and regulating the work of the organization in terms of sanation transformations.

Economic situation in Ukraine is characterized by the presence of a large number of enterprises that are in a crisis. This problem was relevant at the beginning of the independence of Ukraine, just as it is now. The relevance of research into the problems of managing rehabilitation at industrial and commercial associations (ICAs) is explained by the need in innovative scientifically grounded methods of managing economic processes to ensure economic security.

The presence of significant divergencies in the theory and practice of providing economic security while managing sanation transformations in ICAs predetermine the necessity of developing theoretical-methodological and methodical bases of formation and application of approaches to ranking causes of management crisis situations in ICA. The need for scientific development of these tasks taking into account the characteristics of the domestic economy led to the choice of research theme, identified its goals and objectives.
Analysis of recent studies and publications. Assessing approaches of Ukrainian and foreign scientists [1-10 etc.] as well as practical tools, it should be stressed that in ranking causes of managerial crisis situations that emerge in ICAs it is necessary to strictly stick to the strategic plan to ensure economic security of an ICA development.

Significant contribution to the development of the theory and methodology of enterprise management during rehabilitation has been made by works of the following authors: E. Altman, I. Blank, V. Beaver, I. Balabanov, M. Kizim, E. Korotkov, O. Kuzmin, M. Pushkar, P. Pererva, L. Sukhareva, R. Smith, L. Burton, M. Porter, O. Trydìd, Z. Shershniova, I. Alekseyev, A. Moroz, M. Zveryakov, M. Carlin, O. Tereshchenko and others. However, the existing diversity of views on this important category requires attention and development of methodological principles of ranking causes of managerial crisis situations in ICAs in conditions of the changing environment to ensure the viability and competitiveness of the ICA.

The purpose of the study is the improvement of theoretical-methodological and methodical bases of formation and use of approaches to ranking causes of managerial situations in ICAs to ensure economic security while managing rehabilitation transformations in ICAs.

Summary of the basic material. Creation of industrial and commercial associations makes it possible to integrate production with finances and science, as within the ICA it is possible to redistribute resources in favor of enterprises that are at the stage of innovative transformations. Introduction of innovative technologies, modern equipment and new technological processes into production requires changes in the system of rehabilitation transformations management. In production and technology this is provided by using uniform production lines, automation of production and production management. Significant 


\section{C. Bondarchuk}

changes also occur in the financial-economic, organizational and legal and social spheres.

Modern ICAs take advantage of integration of production with finance, scientific research, design and research developments, i.e., ICAs are characterized by production and technical, financial and economic, social and organizational unity. In conditions of crisis situations in the industrial and commercial associations there are taken the appropriate rehabilitation measures that are the objects of economic security in ICAs management.

Having analyzed a significant number of sources the author developed the classifier of management problem situations in ICAs, which permits to accurately reflect and forecast the situations development as well as affect the assessment of managerial problems solutions: the more complicated is the predictable situation, the more urgent its solution is. The classification of managerial situations features is offered in the form of a $3 \mathrm{D}$ model that is reduced to the final result of the ICA activities.

Based on the concept of rehabilitation management in the ICA and provision of economic security, the paper presents peculiarities of the situational approach. So, the management situation is the characteristics of conditions of a ICA and its participants, which, from the point of view of the subject, can be satisfactory or unsatisfactory. In the latter case the situation becomes problematic and characterizes the real discrepancy of the desired and actual levels of meeting the needs of the subject. One and the same problem situation is formulated as different problems. Target orientation in the characteristics of the organization activities and its external environment should be the main one when detecting the signs of problem situations. Note that all situations are related, first of all, either to implementation of previously established objectives (performance of production program, reconstruction, modernization, personnel professional development etc.) or formation of new objectives (the ICA development process). Thus, problem situations occur either in the process of functioning of the organization, or in the process of its development. During the solution of crisis situations in the organization, i.e. during affecting the organization with the aim of transferring it into the desired state, a kind of target activities is chosen from the following options: the source of the situation as well as the object of influence is inside the ICA; the source of the situation is in the external environment while the object of influence is inside the organization; the source of the crisis may be both outside and inside the organization while the object of influence is in the external environment. Like any other kind of management, the process of solving situations during rehabilitation is realized according to the determined cycles of management, starting from the stage of the situations identification and finishing with the stage of solving them. Information about the situation (problem, crisis, etc.), which comes to the internal and external environments of the management system is transformed into solutions that are implemented by the influences that are aimed at one or more subsystems of the ICA and the external environment to ensure economic security.

It is substantiated that in the process of solving the situational tasks of management, identification and ranking of causes of crisis situations in the ICAs are of considerable practical interest. Awareness and evaluation of the importance of these causes allow to more thoroughly distribute resources while designing technologies for solving management situational tasks. We agree with the thoughts of many foreign and Ukrainian scholars to adopt the so-called problem trees as a model of the situations emergence and development processes, as it was already mentioned. The result of the analysis of the problem tree is a list of the minimum-inclusion sets the elementary events. Minimum-inclusion means that nonoccurrence of any of input events leads to the fact that the situation does not occur. Each of the elementaryevents sets actually represents a cause of the problem situation emergence. Getting this list allows exploring the relationships and the importance of both individual elementary events and their sets. To this end, on the sets of elementary events and complex causes of the situation there are introduced measures of similarity on which the ranking of these causes is based.

Information about the complex causes and the elementary events is presented in the form of a matrix. Its rows correspond to the minimum inclusion sets of elementary events (that cause the occurrence of problem situations), and its columns correspond to the problem tree elementary events. The number of rows of the matrix is equal to the number of complex causes, and the number of columns is the number of elementary events. An 


\section{Approaches to ranking causes of management crises in an industrial and commercial association}

element of the matrix is assumed to be one, if it is located at the intersection of such a row and a column of the matrix that an elementary event corresponding to the column is a part of the complex cause corresponding to the matrix rows. Otherwise, an element of the matrix is assumed to be zero. The matrix of the presented type can be considered to be the characteristic function. When studying the characteristic function it is possible to reveal the structure of relationships of both the set of the situations complex causes and the set of the problem tree elementary events. The complex causes of situations are related because some of them having common elementary events. The elementary events can be assumed to be interrelated because of their joint participation in complex causes.

Let us present the structures, describing the relationship of complex causes and the relationship of elementary events, in the form of columns and rows of the characteristic function. To determine the relationship between Boolean vectors, you can use the similarity values identified by them $[1 ; 2 ; 6]$. It is convenient to introduce the Boolean vectors similarity values in terms of a taxonomic table

\begin{tabular}{|c|c|}
\hline$a$ & $b$ \\
\hline$c$ & $d$ \\
\hline
\end{tabular}

where $a$ is the number of matches in two Boolean vectors; $b$ is the number of units that are only in the first Boolean vector; $\mathbf{c}$ is the number of units that are only in the second Boolean vector; $d$ is the number of units absent in both vectors.

$a$ can be seen as the result of the scalar product of two Boolean vectors; $b$ is the difference between the scalar product of the first Boolean vector multiplied by itself and $a ; c$ is the scalar product of the second Boolean vectors multiplied by itself minus $a$; $d$ is the difference between a unit Boolean vector and the vector that is formed from two output Boolean vectors by "OR" logical operation. In terms of the taxonomic table it is convenient to write the equations that explain the content of its components:

\begin{tabular}{|c|c|}
\hline$a$ & $b$ \\
\hline$c$ & $d$ \\
\hline
\end{tabular}

In this case, the sums mean the following: $a+b$ is the number of units in the first vector; $a+c$ is the number of units in the second vector; $c+d$ and $b+d$ are the number of zeros in the first and second vectors, accordingly; $S=a+b+c+d$ is the dimension of the Boolean vector.

So, in terms of the taxonomic table, you can enter a number of legitimate values of similarity. The simplest similarity value defined on the set of elementary events may be the similarity matrix:

$$
R_{1}^{i j}=a_{i j} .
$$

In case of determining the similar pairs of elementary events, the elements of the similarity matrix main diagonal will be the number of those complex causes of the situations occurrence the given elementary event is part of. The non-diagonal element of the similarity matrix (rij) is determined by the number of complex causes of the situations in which there are simultaneously present $i$ and $j$ elementary events.

Analogous similarity matrix can be defined on the set of pairs of complex situations causes. The elements of its main diagonal include the number of elementary events that determine the specific causal complex. The non-diagonal elements are determined as the number of elementary events common for $i$ and $j$ causal complexes of situations. A more complex similarity value is obtained from equation (1) by bringing it to unit:

$$
R_{2}^{i j}=a_{i j} /\left(a_{i j}+b_{i j}+c_{i j}\right) .
$$

Using this similarity value, let us neglect the number of elementary events and causal complexes of situations. Transition to the relative values in the similarity value makes it more convenient to compare, for example, the role of elementary events in the development of situations being described using different problem trees.

In determining similarities of elementary events and their sets, the similarity values (1) and (2) take into account only the number of common elements of the situations. The similarity can be also determined by simultaneous absence of these elements. The similarity value of this type is determined by modifying value (2):

$$
R_{3}^{i j}=a_{i j}+d_{i j} /\left(a_{i j}+b_{i j}+c_{i j}+d_{i j}\right) .
$$

When determining similarity of two causal complexes, $\mathrm{d}_{\mathrm{ij}}$ is interpreted as the number of elementary events that are simultaneously absent in them. When the relationship of two elementary events is studied as to their being part of a set of casual complexes, dij represents the number of causal complexes that do not contain these elementary events simultaneously. Similarity value (3) also approximates the unit. 


\section{C. Bondarchuk}

It should be noted that on the basis of each of the values of similarity there can be built the difference index. It is convenient to do this by supplementing the measurement of similarity to the maximum:

$$
R_{\text {difference }}^{i j}=R_{\text {max }}{ }^{i j}-R_{\text {similarity. }}^{i j} \text {. }
$$

Introduction of similarity values to certain concepts (such as "elementary events" and "complex causes of situations") is not intended as concealment by using mathematical symbols. This is justified by both the necessary to characterize the degree of similarity of structured objects and the possibility to get a search result with a simple, meaningfully interpreted procedure. Important is the fact that the similarity values used are metrics and this fact gives ground, while analyzing the similarity matrix, for applying a great number of rigorous and heuristic methods developed within the concept of data analysis.

Similarity matrices contain full information on relationships of both complex causes and elementary events. Using this information, it is necessary to start ranking both these phenomena. In this case, of course, there is some loss of information, but the resulting rankings are a convenient tool for practical use in the process of solving tasks of handling situations in conditions of the changing environment. The idea of the similarity matrix starting ranking is as follows. Firstly, the higher the degree of an elementary event interconnection with other elementary events is, the more important it is considered to be. Secondly, the closer the given complex cause of the situation occurrence is related to other complex causes of the situation occurrence in conditions of the changing environment, the more important it is.

Let us define the importance of an elementary event as the sum of values of its interrelations with other elementary events. As a measure of the relationship let us use the numerical value of the similarity of the event with other elementary events:

$$
V_{i}=\sum r_{i j} .
$$

Summing the similarity values in (5) is performed for all elementary events, excluding the given one. The resulting estimate of the importance of the event is only the first approximation, since here all the relationships of the event are included as equal, at the same time the elementary events being not equal in importance. Therefore, in the iterative calculation of the elementary events importance that is necessary for their ranking, one needs to consider the estimates obtained in the subsequent iterations:

$$
V_{i}^{k}=\Sigma\left(V_{i}^{k-1} / \sum V_{i}^{k-1}\right) r_{i j} .
$$

Obtained during the calculation of $V_{i}$ are the elements of its own vector corresponding to the maximum eigenvalue of the reduced similarity matrix. Similarly, you can get the quantitative evaluation of the importance of complex causes of the need of ICA in rehabilitation. The obtained evaluations are sure to determine the ranks of both elementary events and complex causes of the situations occurrence in conditions of the changing environment.

It should be noted that the similarity matrix permits to solve a number of other tasks of economic security and situational management in ICAs, for example:

1) designing management procedures focused on groups of similar causes of the problem situations occurrence. To do this, on the basis of the similarity matrix analysis, using algorithms of cluster analysis and automatic classification there are specified homogeneous groups of causes of the problem situations occurrence in ICAs;

2) visualizing a set of the problem situations causes with minimal loss of the structure and interrelations that permits to take more thorough decisions concerning the effects on this or that unit of the ICA. For this purpose there is used the method that is similar to the method of the main component that allows, with minimal geometric differences, to present the structure of the process of emergence and development of the need in rehabilitation.

Conclusions. The proposed concept of solving situational tasks of rehabilitation management and methodical bases of its realization in the system of industrial and commercial associations permit to classify the managerial situations, typical procedures and methods of their solution, the structure of the management information database in an integrated way and effectively ensure the economic security of the ICA. The feasibility of implementing the situational approach in the management of ICA is due to the necessity of the organizational structures improvement during taking rehabilitation measures. Predicting problem situations that arise in the organization at all stages 
Approaches to ranking causes of management crises in an industrial and commercial association

of its operation, permits to develop in advance the procedures to deal with them with regard to restrictions over the period of developing a managerial decision and impact, the availability of human, material and financial resources as well as the scientific and technical basis as conditions of the economic security of the ICA.

\section{References}

1. Андрушків Б. М. Основи теорії та практики управління / Б. М. Андрушків. - Львів: Світ, 1993. $-204 c$.

2. Бондарчук М. К. Управління санаиією виробничогосподарських об'єднань: автореф. дис. ... д-ра екон. наук: 08.00.04 / М. К. Бондарчук // Начіональний університет "Львівська політехніка", 2013.

3. Берж К. Теория графов и ее применение / К. Берж. - М.: Иностранная литература, 1962.

4. Економічна безпека підприємства, організацій та установ: навч. посіб. / [В. Л. Ортинський, I. С. Кернищький, 3. Б, Живко та ін.]. - К.: Правова єдність. - 2009. - 544 с.

5. Колісник М. К. Антикризове управління виробничогосподарськими структурами у машинобудуванні: монографія / М. К. Колісник. - Львів: Вид-во Нац. ун-ту “Львівська політехніка". - 2009. - 232 с.
6. Ярочкин В. Система безопасности фирмы: концепчии, правовые основы / В. Ярочкин. - М.: Ocb-89. - 1997. - 350 c.

7. Экономическая безопасность предпринимательской деятельности. Методическое пособие для предпринимателя / Сост.: Б. Н. Торянников, А. П. Красковский. - СПб.: ЗАО "Информаиионное агентство "Кредит реформа-СанктПетербург", 2000. - 160 c.

8. Терещенко О. О. Антикризове управління фінансами підприємств: автореф. дис. ... докт. екон. наук: 08.04.01 / О. О. Терещеенко. - Київ: Київський наиіональний економічний університет. - 2005

9. Gerisch R. Aufgaben und Probleme der Entwicklung in den Kombinaten zur Erhonung der volkswirtschaftlichen Efektivitat / R. Gerisch, W. Hofmann. In Wirtschaftswissenschaft, Berlin 27 (1979) 2. - S. 139.

10. Gustmann K.-H. Intensivierungs-faktoren Produktionorganisation / K.-H. Gustmann, G. Stolzenberg, H.-P. Wolff, Verlag Die Wirtschaft, Berlin 1978. - S. 75.

11. Gabler U. Erarbeitung eines Algoritmus zur Balanzierung des Produktionsprogrammes ausgehed von der Intensivierungskonzeption bis zum Jahresplan I U. Gabler, Forschungsbericht, Friedrich-SchillerUniversitat, Jena, 1979. - S. 31ff.

12. Koziolek H. Wirtschaftswachtum und Entwicklung der materiell-technischen Basis / H. Koziolek, Wirtschaftswissenschaft, Heft 3/1982. 
